\title{
NASA Green Flight Challenge: Conceptual Design Approaches and Technologies to Enable 200 Passenger Miles per Gallon
}

\author{
Douglas P. Wells ${ }^{*}$ \\ NASA Langley Research Center, Hampton, Virginia 23681
}

\begin{abstract}
The Green Flight Challenge is one of the National Aeronautics and Space Administration's Centennial Challenges designed to push technology and make passenger aircraft more efficient. Airliners currently average around 50 passenger-miles per gallon and this competition will push teams to greater than 200 passenger-miles per gallon. The aircraft must also fly at least $\mathbf{1 0 0}$ miles per hour for $\mathbf{2 0 0}$ miles. The total prize money for this competition is $\$ 1.65$ Million. The Green Flight Challenge will be run by the Comparative Aircraft Flight Efficiency (CAFE) Foundation September 25 - October 1, 2011 at Charles M. Schulz Sonoma County Airport in California. Thirteen custom aircraft were developed with electric, bio-diesel, and other bio-fuel engines. The aircraft are using various technologies to improve aerodynamic, propulsion, and structural efficiency. This paper will explore the feasibility of the rule set, competitor vehicles, design approaches, and technologies used.
\end{abstract}

\section{Nomenclature}

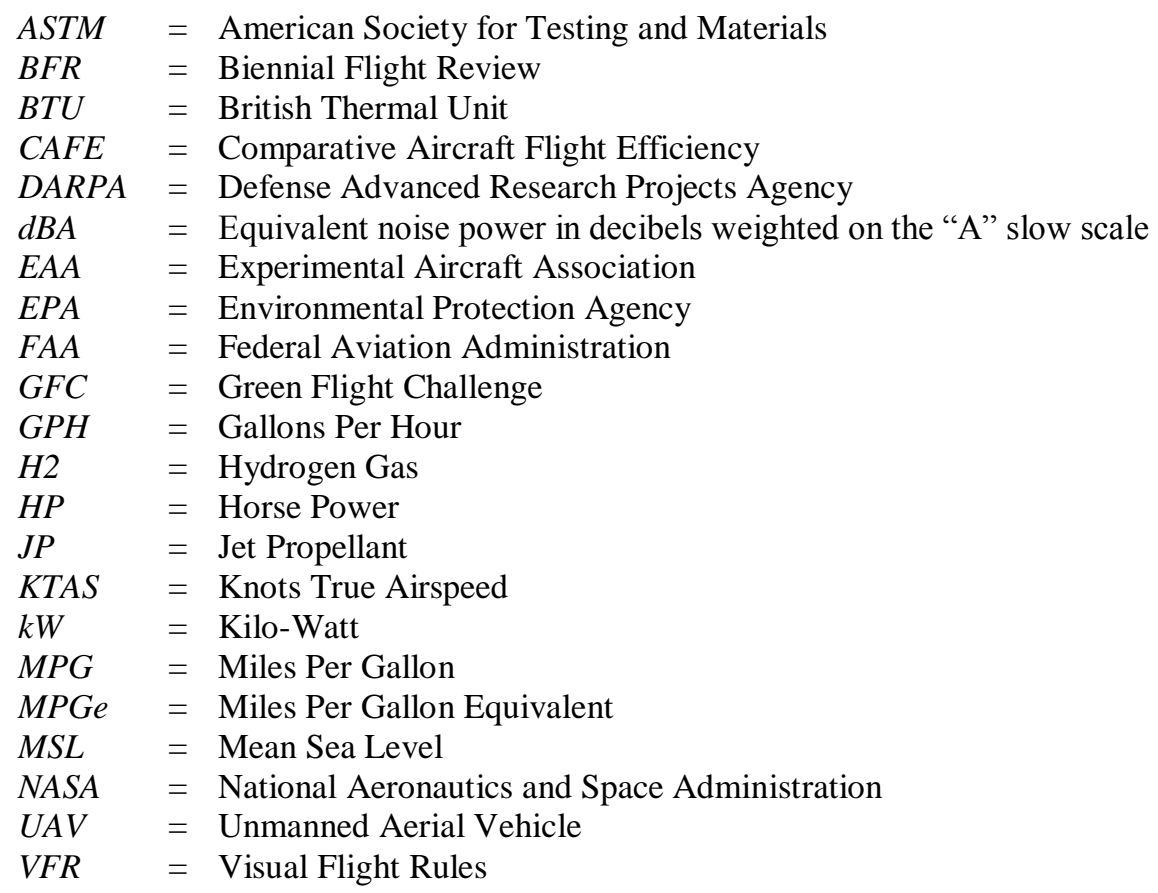

*Aerospace Engineer, Aeronautics Systems Analysis Branch, MS 442, AIAA Member. 


\section{Introduction}

$\mathrm{I}_{\mathrm{in}}^{\mathrm{n}}$ the growing pursuit of more environmentally friendly and efficient travel, researchers, technologists, and inventors are pushing the limits of our current technology. Luxury and speed are no longer the primary objectives. Environmental taxes and laws restricting emissions and pollution are beginning to drive the design of our future transportation vehicles. NASA funded the Green Flight Challenge to push current technology and explore the technology gaps which must be closed to achieve the environmentally friendly and efficient travel goals for the future.

There is a long history of aviation prizes. Raymond Orteig offered \$25,000 in 1919 to the first successful nonstop flight from New York, New York to Paris, France or vice versa. The Orteig Prize was won by Charles Linbergh in 1927 with the Spirit of St. Louis. Henry Kremer established the Kremer Prizes in 1959. He offered \$100,000 for the first prize competition which was for the first human-powered aircraft to fly one mile. The prize was won by Paul McCready in 1977 with the Gossamer Condor flown by Bryan Allen. ${ }^{1}$ Other notable prizes are the $\$ 250,000$ Sikorsky human powered helicopter prize, \$2 Million Defense Advanced Research Projects Agency (DARPA) Grand Challenge: Urban Challenge, \$2 Million DARPA UAV Prize, \$10 Million Ansari X-Prize, $\$ 60,000$ Experimental Aircraft Association (EAA) Electric Flight Prize, and the NASA Centennial Aviation Challenges. NASA's first challenge was the $\$ 250,000$ Personal Air Vehicle Challenge in 2007. Four competitors participated and $\$ 250,000$ was awarded. It was followed by the $\$ 350,000$ General Aviation Challenge in 2008 which only awarded $\$ 97,000$ to its three participants. ${ }^{\dagger}$

The early aviation prizes had a tremendous impact on the aviation industry. The Orteig Prize changed the public's expectations of flying. Charles Lindbergh's flight across the Atlantic created the expectation that anyone could fly. Three major impacts were observed: in 1927, U.S. pilot license applicants increased by $300 \%$ and the number of U.S. licensed aircraft increased by $400 \%$; and there were 30 times the number of U.S. airline passengers in 1929 as there were in $1926 .{ }^{*}$ The new technologies and innovations from the Kremer prize led to new niche markets. Efficiently using power from batteries contributed to the development of the electric powered car and solar powered aircraft. The lightweight soaring capability contributed to high altitude projects such as the NASA Pathfinder aircraft. ${ }^{2}$ Air races like the Schneider Trophy in the 1920s and 1930s pushed airplane and airplane engine performance. New liquid cooled engines were introduced to provide more powerful engines. The airframes were clean and efficient. These races accelerated aircraft speeds from $150 \mathrm{mph}$ to $400 \mathrm{mph}$ in 13 years. ${ }^{\S}$

The CAFE Green Flight Challenge is one of NASA's Centennial Challenges. Centennial Challenges is a program that supplies incentive prizes to create solutions to problems of interest to NASA and the nation. The challenges were inspired by other prizes like the Ansari X Prize and agencies that fund prize competitions like the DARPA. NASA's program is searching for innovation from diverse and non-traditional sources. The challenge was announced at the EAA AirVenture 2009 in Oshkosh, WI. ${ }^{3}$

The objective of the Green Flight Challenge is to achieve 200 passenger-miles per gallon or better with an average speed of at least $100 \mathrm{mph}$ with a range of 200 miles. There will be competitive flights, one to achieve best equivalent passenger-miles per gallon ( $\mathrm{mpg}$ ) and the second to achieve best speed. Both flights must maintain a minimum average speed of $100 \mathrm{mph}$ and minimum efficiency of 200 passenger-mpg. Having two flights focused on different objectives promotes a robust design. The Green Flight Challenge is the largest aviation prize ever with a total prize amount of $\$ 1.65$ million. First prize for the highest score is $\$ 1.3$ million. Five runner-up prizes of $\$ 200,000$ total and a $\$ 150,000$ prize for the most efficient bio-fuel aircraft will also be awarded. ${ }^{4,5}$

\footnotetext{
* "2007 NASA PAV Challenge Results” was accessed from the CAFE Foundation website URL: http://cafefoundation.org/v2/pav pavchallenge 2007 results.php on 26 August 2011.

$\uparrow$ "2008 NASA GAT Challenge Results" was accessed from the CAFE Foundation website URL: http://cafefoundation.org/v2/pav gatchallenge 2008 results.php on 26 August 2011.

$\$$ "Incentivized Competition Heritage" was accessed from the X PRIZE Foundation website URL: http://xprize.org/xprizes/incentivized-competition-heritage on 26 August 2011.

$\S$ "The Schneider Trophy" was accessed from the Air Racing History website URL: http://www.air-racinghistory.com/Schneider.htm on 26 August 2011.
} 


\section{Historical Data}

Jet Propellant (JP) and 100 low-lead (LL) fuels are still being used in aircraft. These fuels can produce relatively high levels of emissions compared to automobiles. Some of these by-products are nitrogen-oxide, carbon dioxide, and lead. Use of these fuels is unregulated by the Environmental Protection Agency (EPA) and falls under the Federal Aviation Administration's jurisdiction. Bio-fuels and electric power have the potential to drastically reduce aviation emission levels.

State of the art aircraft efficiency is low compared to state of the art automobiles when the passenger-mpg metric is used. The state of the art airliner, the Boeing 787 is estimated to reach around 100 passenger-mpg. *For comparison, the current airline industry averages 50.5 passenger-mpg, ${ }^{\dagger}$ the general aviation aircraft average in 2000 was 10 passenger-mpg, ${ }^{6}$ and sailplanes can achieve near infinite passenger-mpg, but they typically fly up to $70 \mathrm{mph}$ and are somewhat unreliable. The state of the art automobile, the Toyota Prius can achieve 200 passenger-mpg.

Four popular general aviation aircraft are shown in Table 1, compared in terms of the Green Flight Challenge metrics. Data used is from the respective Pilot Operating Handbooks. ${ }^{7,8,9,10, \$}$ Best economy power and mixture was used at 8000 foot altitude. While the entire mission was not examined, the data give an idea of where current general aviation aircraft would score in the Green Flight Challenge.

Table 1. Four popular general Aviation aircraft compared with Green Flight Challenge Metrics.

\begin{tabular}{|c|c|c|c|c|}
\hline Aircraft Manufacturer & Cessna Aircraft & Cirrus Design & Hawker Beechcraft & Piper Aircraft \\
\hline Aircraft Type & 172 Skyhawk & SR22 & G36 Bonanza & Cherokee Archer III \\
\hline Cruise Fuel Flow (GPH) & 7.8 & 11.3 & 9.8 & 8.2 \\
\hline Cruise Speed (KTAS) & 106 & 160 & 149 & 107 \\
\hline MPG & 15.64 & 16.29 & 17.50 & 15.02 \\
\hline Passenger-MPG & 62.56 & 65.18 & 104.98 & 60.07 \\
\hline
\end{tabular}

Figure 1 shows aircraft efficiency by year. The Green Flight Challenge will push aircraft to about double the highest passenger-mpg shown.

\footnotetext{
* "Will the Dreamliner Soar?" was accessed from the Time Business website URL: http://www.time.com/time/business/article/0,8599,1641341,00.html on 24 August 2011.

$\dagger$ “ATA News Release: ATA Releases Enhanced Quarterly Airline Cost Index” was accessed from Air Transport Association website URL: http://www.airlines.org/News/Releases/Pages/news 10-31-06b.aspx on 24 August 2011. $\$$ "Prius 11" was accessed from the Toyota website URL: http://www.toyota.com/prius-hybrid/specs.html on 24 August 2011.

§ "G36 Bonanaza N936EW" was accessed from the Plane \& Pilot Magazine website URL: http://www.planeandpilotmag.com/aircraft/specifications/beechcraft/g36-bonanza-n936ew.html on 18 August 2011.
} 


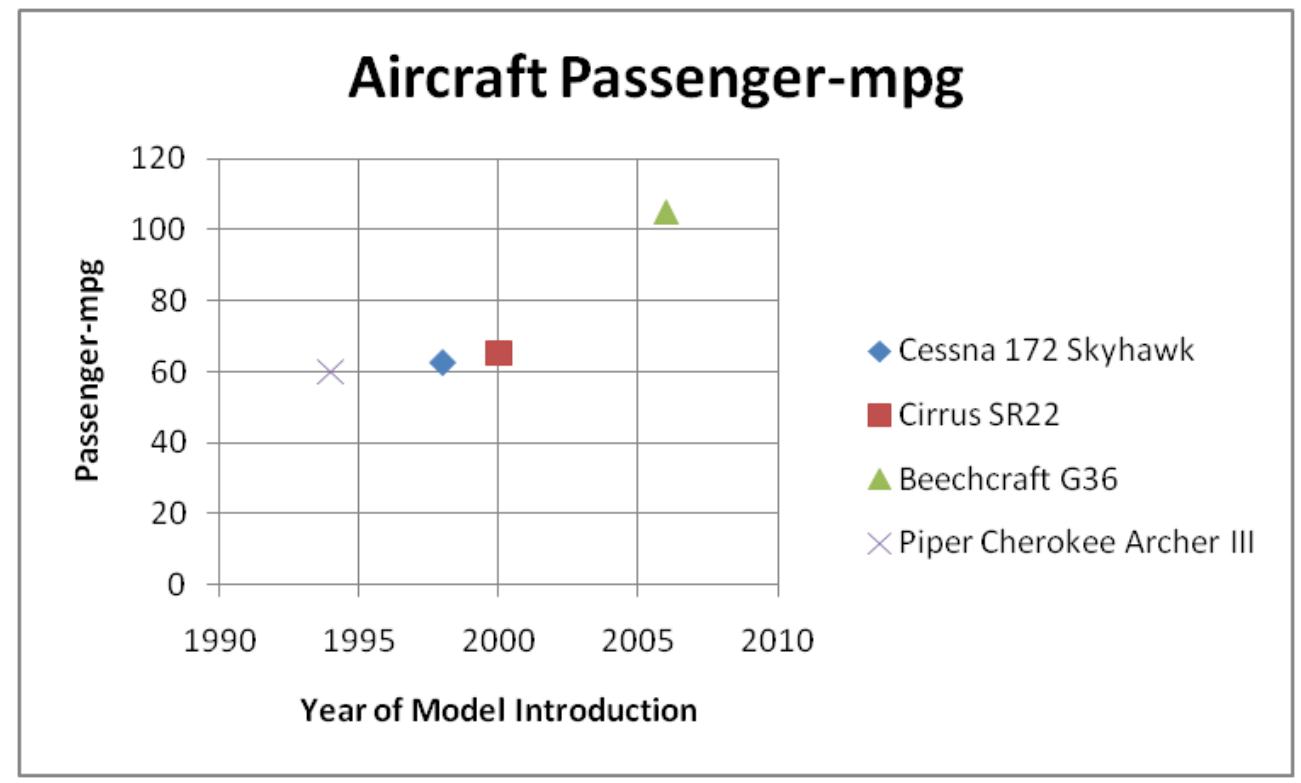

Figure 1. Efficiency of four general aviation aircraft.

\section{Motivation}

The Centennial Challenges are part of NASA's Early-Stage Innovation programs. They are designed to encourage high risk-high payoff ideas. If these ideas are successful, they will transition for further development in other Early Stage or Game-Changing programs or be adopted by other government or commercial efforts. The Centennial Challenges aim to drive innovation. They are important because they accelerate technology development.

NASA's motivation for the Green Flight Challenge is to advance technologies in fuel efficiency and to reduce emissions, which fall in line with its mission to pioneer and prove new flight technologies. The green aviation goals are to enable fuel-efficient flight planning and reduce aircraft fuel consumption, emissions, and noise. The Green Flight Challenge will push technologies for reduced fuel consumption and emissions through the high, 200 passenger-mpg performance requirement. There is also a noise level limit of $78 \mathrm{dBA}$ at full power takeoff to encourage development of low noise technologies.

\section{The Design Problem}

The Green Flight Challenge is a focused problem with many constraints, making it a difficult design problem to define. The score is based on speed and passenger-mpg with more weight on the passenger-mpg. The primary objective should be to maximize passenger-mpg and the secondary objective should be to maximize speed.

The ideal aircraft would have sailplane-like efficiency while achieving good operating capabilities that most current sailplanes do not possess. Those operating capabilities are compactness for ground handling, good gust handling characteristics through high wing loading, high cruise speed, and short takeoff distance using high lift devices.

Some of the key variables are span, wetted area, aspect ratio, empty weight, gross weight, fuel or energy capacity, and propulsive power. Span, wetted area, and aspect ratio will provide some insight into the aerodynamic efficiencies. Structural efficiencies can be examined by looking at the empty and gross weights. Additionally, fuel or energy capacity and power-to-weight will provide some insight into the propulsion efficiencies.

Past competitions such as the CAFE 400s, show participants did attack the three main efficiency areas. Some of the technologies and advancements that attacked aerodynamic efficiency were laminar flow surfaces, leakage drag reduction, flush antennae, and cowl flap design improvements. Propulsion system technologies included high intensity ignition systems, lean of peak mixture settings, special propeller designs, and cowl flap design improvements. Structural efficiency technologies mostly involved creating lighter structure using high tech composite materials. The Green Flight Challenge will require more technology advancement in different areas like 
electric propulsion. There is a long list of technologies being considered for this competition because it is pushing for efficiency beyond what is currently available.

\section{The Competition}

The Green Flight Challenge will be held September 25 - October 1, 2011 at the Charles M. Schulz Sonoma County Airport in California. Nine teams are registered to compete in the competition. Current registration does not guarantee the teams will participate in the competition. Each team must complete 40 hours of flight in the vehicle and obtain FAA Registration and an Airworthiness Certificate. Some of the early teams that droped out simply did not complete enough fabrication to achieve the FAA inspection threshold. ${ }^{4}$

\section{A. The Contest Rules}

The detailed set of rules can be found starting on page 18 in the Green Flight Challenge Team Agreement ${ }^{4}$. Rules are a necessary part of any competition. It was highly desirable to have a simplistic set of rules for the competition to allow creative and innovative solutions to the challenge. However without real world constraints, the resulting vehicles would most likely be meaningless. The goal of the competition is to create vehicles and technologies that will enable more efficient air travel that is at least as safe as present day, not just to create innovative competition vehicles. NASA, CAFE, and the potential entrant community spent over a year debating and negotiating over the rules. Next, draft rules were provided to interested parties during a rulemaking consensus period. Comments from this period were collected and integrated into the final rule set.

\section{The Green Flight Challenge Rules Summary}

The following rules summary was taken from Appendix A of the Green Flight Challenge Team Agreement and updated with the revised prize structure. ${ }^{4,5}$

Main Prize: $\quad \$ 1,300,000.00$ US for the one vehicle with $\geq 100 \mathrm{mph}$ AND $\geq 200$ Passenger-MPGe that achieves the best combination of mph and Passenger-MPGe by the following formula:

$\begin{array}{ll} & \text { Score }=1 /((1 / \mathrm{mph})+(2 / \text { Passenger-MPGe })) * \\ \text { Other Prizes: } & \text { Bio-Fuel Prize and Honorary Achievement Prize }\end{array}$

\section{Performance Required:}

Range:

Efficiency:

Speed:

Minimum Speed:

Takeoff Distance:

Community Noise:

Handling Qualities:

\section{Features Required:}

Passengers:

Wingspan:

Vehicle Weights:

Field of View:

Control System:

Payload Carried:

Seating Configuration:
200 statute miles, with 30 min. reserve, day VFR at $\geq 4000^{\prime}$ MSL over nonmountainous, sparsely-populated coastal terrain

$\geq 200$ Passenger-MPGe energy equivalency

$\geq 100 \mathrm{mph}$ average on each of two 200 mile flights

$\leq 52 \mathrm{mph}$ in level flight without stall, power and flaps allowed

$\leq 2000$ feet from brake release to clear a 50 foot obstacle

$\leq 78 \mathrm{dBA}$ at full power takeoff, measured 250 feet sideways to takeoff brake release

Acceptable on all 7 basic handling qualities.

Upright seats with adequate volume for a 6-foot tall, 200 pound (lb) adult.

Must fit inside 44-foot wide hangar for weighing (wingfold is acceptable). Height, length and landing gear footprint limits are defined in the Green Flight Challenge Team Agreement.

$\leq 6500 \mathrm{lb}$. with $\leq 4500 \mathrm{lb}$. on main gear and $\leq 2000 \mathrm{lb}$. on nosewheel or tail-wheel

Acceptable to FAA licensing authorities and FAA AC25.773-1

Must provide dual controls if two or more seats

$200 \mathrm{lbs}$ per seat. Dual pilots if two or more seats. $200 \mathrm{lbs}$ per seat sandbag ballast in all seats not occupied by pilot/co-pilot

Tandem seating is allowed, but vehicles with 3 or more seats must place at least 2 seats directly side-by-side. Rapid exit required for all seats.

American Institute of Aeronautics and Astronautics 
Fuel/Energy Use: $\quad$ Energy consumed: 1 gallon of 87 octane unleaded auto gasoline $=115,000$ BTU. See table of energy equivalents for all allowable fuels/energy sources in the Green Flight Challenge Team Agreement.

Fuels/Energy Allowed: Avgas 100 low-lead (LL), Jet-A, diesel, unleaded auto gasoline, bio-fuels, H2, synthetics, electricity.

ePower Measurement: Electric-powered aircraft will use a CAFE-provided power meter to accurately determine energy used during the competition

Flightworthiness: $\quad$ Valid US FAA Airworthiness Certificate for unrestricted day VFR flight in the Continental United States, proof of structural limits, ASTM 2316 compliant vehicle ballistic parachute and all applicable inspections.

Pilot Qualifications: $\quad$ FAA qualified for operating experimental aircraft, with current medical, BFR, 500

flight hours total and 10 flight hours in make \& model

Eligibility:

Early Bird Entry Fee:

Team leader must be a U.S. Citizen or permanent resident

Design Proposal:

$\$ 4000$ if submitted before December 31, 2009

Design Freeze:

Required before acceptance by CAFE into the event

After official registration and weigh-in no modifications to the vehicle are allowed.

Additional Relevant Documents:

Team Agreement and all of its Appendices, FAA AC25.773-1 (field of view regulations)

Updates and FAQs: Visit http://cafefoundation.org

Additional Requirements:

Nothing except water ballast may be jettisoned from the vehicle during flight; weight of discarded water ballast will be scored as fuel consumed

* Passenger-MPGe = number of passengers (pilots, passengers or seats with equivalent ballast) multiplied by the calculated vehicle miles per gallon equivalent for the fuel and/or electricity referenced to the average energy content of 1 gallon of 87 octane unleaded auto gasoline (115,000 BTU) (for example: 200 passenger-MPGe $=2$ seats $\mathrm{x}$ $100 \mathrm{Ge}$ for a 2-passenger aircraft.)

\section{Mission Threshold Rules: Efficiency, Speed, Range, Payload}

Minimum thresholds were set for the competition based on the current state of the art technology and vehicle performance. The current state of the art was determined based on analysis of general aviation aircraft and motor gliders. Prior CAFE efficiency races were examined to determine the best passenger-mpg for an internal combustion engine, which was 100 passenger-mpg. At least two times the previous achievement was desired for the Green Flight Challenge, thus the 200 passenger-mpg threshold was set.

In the same manner that the efficiency threshold was set, the speed, range and payload were also set. One of the major factors in setting the speed was block travel time. For general aviation travel to be worthwhile, it was determined that an average block speed of $100 \mathrm{mph}$ was required. This would make trip time in an airplane faster than taking the same trip in an automobile. Therefore, the minimum average speed was set at $100 \mathrm{mph}$.

Range and payload were determined based on desired minimum trip requirements. An airplane that could not fly at least 200 miles would have too short of a range to be practical. The more seats that are in an airplane, the more practical it is. The scoring formula exposes this through passenger-mpg. The number of passengers has a direct effect on the total score. Forty pounds of additional weight per seat is required to allow for passenger baggage.

\section{Design Constraints: Noise, Takeoff Distance, Minimum Speed}

Constraints were added to ensure practical operating solutions in the competition vehicles. During the rulemaking period, many different design approaches were discussed. The constraints were selected to prevent solutions that work around the efficiency problem with impractical designs. Some of the solutions discussed that are 
not permitted under the final rules include aircraft carrier style catapult launches, cruise-sized wings that takeoff at high speed, and cruise-optimized high speed wingtip propellers.

\section{Safety Constraints: Handling Qualities, Field of View, Seating Configuration}

Safety first! The goal of the competition is to create aircraft that could either be put directly into production or slightly refined before production. Production aircraft need to be safe in order to be certified for flight. Safety rules were put in place to again push the aircraft to more practical solutions. A goal of the competition rule set is to prevent accidents and harm to the participants. Handing quality rules were established to prevent accidents from happening. It was conceivable that the pursuit of higher efficiency would drive an airplane to have improper handling such as pursuing minimum drag solutions. Egress was also a concern and rules for the seating configuration were established.

\section{Practical Constraints: Span, Gross Weight}

The Green Flight Challenge will take place at the Charles M. Schulz Sonoma County Airport in Santa Rosa, California. Several practical constraints exist at the CAFE facility located there. The official scales for weigh-ins are located inside of the CAFE hanger. The span constraint was created because the hanger has a maximum opening of 44 feet. Wing folding and removal is permitted. However, there is a time limit for this transition to allow for the weigh-in time to remain reasonable. The scales have a maximum weight limit which resulted in the 6500 pound main gear limit and the 2000 pound nose or tail wheel limit.

\section{B. The Teams}

Table 2 contains the team data available on the CAFE Foundation website. ${ }^{*}$ The table lists the thirteen teams that that paid the initial entry fee for the Green Flight Challenge.

Table 2. Green Flight Challenge Team Summary.

\begin{tabular}{|c|c|c|c|c|c|c|c|}
\hline Team Name & Team Leader & $\begin{array}{l}\text { Vehicle } \\
\text { Name }\end{array}$ & State & Seats & $\begin{array}{c}\text { Max Power } \\
(\mathrm{kW})\end{array}$ & $\begin{array}{l}\text { Span } \\
\text { (feet) }\end{array}$ & $\begin{array}{l}\text { Energy } \\
\text { Type }\end{array}$ \\
\hline PC Aero & $\begin{array}{l}\text { Einar } \\
\text { Enevoldson }\end{array}$ & Electra 1 & $\mathrm{CA}$ & 1 & 21 & 27.6 & Electric \\
\hline Feuling GFC & Gene Sheehan & $\begin{array}{l}\text { Team } \\
\text { Feuling } \\
\text { GFC }\end{array}$ & $\mathrm{CA}$ & 1 & 16 & 16.7 & Electric \\
\hline $\begin{array}{l}\text { Windward } \\
\text { Performance }\end{array}$ & Gregory Cole & Goshawk & OR & $\begin{array}{l}2 \text { (side- } \\
\text { by-side) }\end{array}$ & NA & 51.0 & Electric \\
\hline Green-Elis & $\begin{array}{l}\text { Lawrence } \\
\text { Speer }\end{array}$ & $\begin{array}{l}\text { Greenelis } \\
\text { PXLD }\end{array}$ & $\mathrm{CA}$ & $\begin{array}{l}2 \text { (side- } \\
\text { by-side) }\end{array}$ & 30 & 35.5 & Diesel \\
\hline Michael Stude & Mike Stude & $\begin{array}{l}\text { Wings of } \\
\text { Salvation }\end{array}$ & KS & 1 & 32 & 16.7 & Ethanol \\
\hline $\begin{array}{l}\text { Embry-Riddle } \\
\text { Aeronautical } \\
\text { University }\end{array}$ & $\begin{array}{l}\text { Richard } \\
\text { Anderson }\end{array}$ & EcoEagle & FL & $\begin{array}{l}2 \text { (side- } \\
\text { by-side) }\end{array}$ & 100 & 75.0 & Hybrid \\
\hline Synergy & $\begin{array}{l}\text { John W. } \\
\text { McGinnis }\end{array}$ & Synergy & MT & 6 & 142 & 32.0 & Bio-diesel \\
\hline GSE-Aerochia & $\begin{array}{l}\text { Greg } \\
\text { Stevenson }\end{array}$ & $\begin{array}{l}\text { Econo- } \\
\text { Cruiser } 3000\end{array}$ & $\mathrm{CA}$ & $\begin{array}{l}2 \\
\text { (tandem) }\end{array}$ & 15 & 48.3 & $\begin{array}{l}\text { Bio-fuel } \\
\text { Hybrid }\end{array}$ \\
\hline IKE Aerospace & Ira Munn & SERAPH & $\mathrm{CA}$ & $\begin{array}{l}2 \text { (side- } \\
\text { by-side) }\end{array}$ & 30 & 15.0 & Electric \\
\hline e-Genius & Eric Raymond & e-Genius & $\mathrm{CA}$ & $\begin{array}{l}2 \text { (side- } \\
\text { by-side) }\end{array}$ & 60 & 55.4 & Electric \\
\hline
\end{tabular}

\footnotetext{
* "10 Teams Officially Registered for 2011 CAFE Green Flight Challenge" accessed CAFE Foundation website URL: http://cafefoundation.org/v2/gfc 2011 teams.php on 18 August 2011.
} 


\begin{tabular}{|l|l|l|l|l|l|l|l|}
\hline Phoenix Air & Jim Lee & PhoEnix & FL & $\begin{array}{l}2 \text { (side- } \\
\text { by-side) }\end{array}$ & 44 & 47.3 & Electric \\
\hline Yuneec & Scott Sanford & $\begin{array}{l}\text { Yuneec E } \\
1000\end{array}$ & CA & 3 & 120 & 56.0 & Electric \\
\hline $\begin{array}{l}\text { Pipistrel - Penn } \\
\text { State University }\end{array}$ & $\begin{array}{l}\text { Jack } \\
\text { Langelaan }\end{array}$ & Taurus G4 & PA & 4 & 145 & 69.1 & Electric \\
\hline
\end{tabular}

\section{PC Aero}

The PC Aero team is led by Einar Enevoldson from California. Their aircraft, Electra 1, is a clean sheet design. This motor glider features a retractable landing gear and an electric motor with 3-bladed propeller. PC Aero is currently registered, has met the FAA inspection, and the Electra 1 is currently flying. Figure 2 is a picture of the airplane in flight."

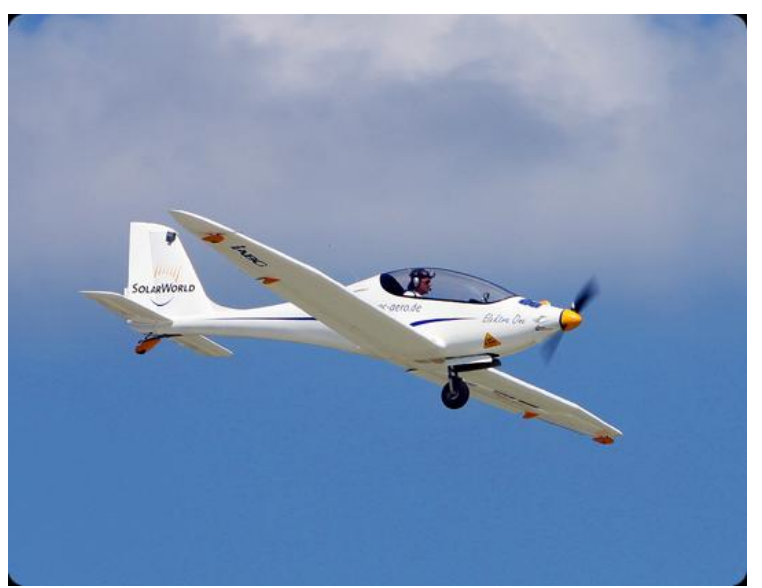

Figure 2. Electra 1. OMichael Mularski, SolarWorld.

\section{Feuling GFC}

The Feuling GFC team is led by Gene Sheehan from California. The Feuling Green Flight Challenger is a Rutan Quickie. The Challenger features an electric motor with a 2-blade propeller, carbon fiber fuselage, and a Kevlar vertical stabilizer. Feuling GFC is currently registered and has met the FAA inspection. Figure 3 is an image of the airplane. $^{\dagger}$

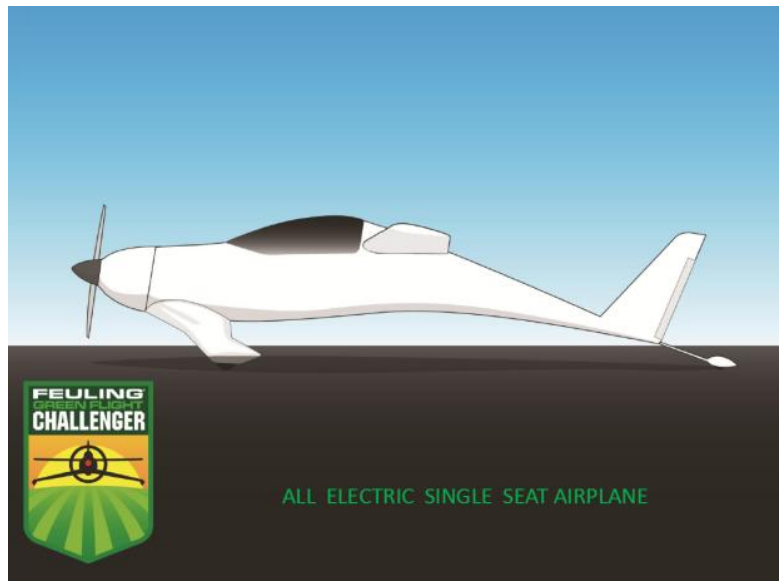

Figure 3. The Green Flight Challenger.

\footnotetext{
* "Electric Powered Aircraft" was accessed from the PC Aero website URL: http://www.pc-aero.de on 18 August 2011.

$\dagger$ "Sponsor Package.pdf" was accessed from the Feuling GFC website URL: http://www.greenflightchallenger.com/sponsorship on 18 August 2011.
} 


\section{Windward Performance}

The Windward Performance team is led by Gregory Cole from Oregon. Their aircraft is the Goshawk. It is a two-seat, all electric motor glider. Windward Performance is currently registered and has met the FAA inspection. Figure 4 is a conceptual picture of the airplane."

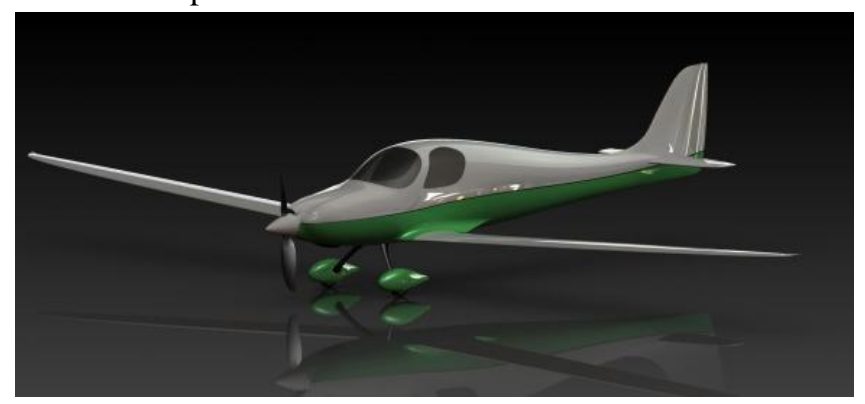

Figure 4. The Goshawk.

\section{Green-Elis}

The Green-Elis team is led by Lawrence Speer from California. Their aircraft, Greenelis PXLD, is a clean sheet design. It features light weight carbon-fiber epoxy, a light weight turbo diesel Mercedes / Smart engine, and two seats. Green-Elis is not registered. Figure 5 is a picture of the aircraft. ${ }^{\dagger}$

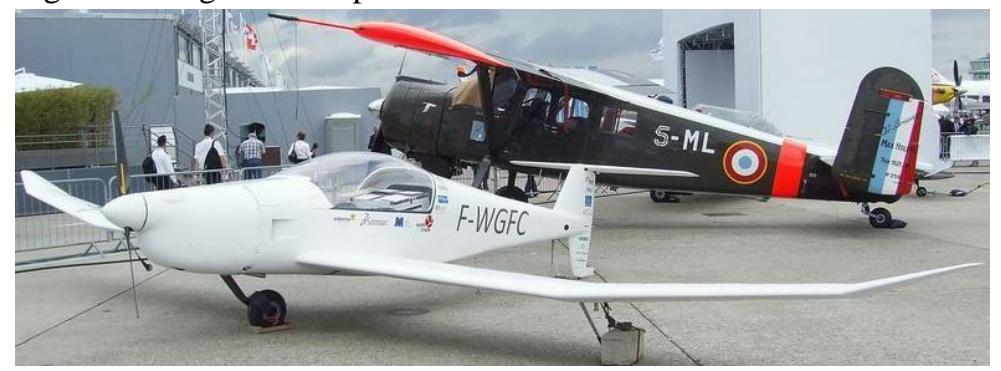

Figure 5. Greenelis PXLD (front). OIngo Warnecke, Airport-Data.com.

\section{Michael Stude}

Team Michael Stude is led by Mike Stude from Kansas. Their aircraft is called Wings of Salvation. This team is not currently registered for the September 2011 Competition.

\section{Embry-Riddle Aeronautical University}

The Embry-Riddle Aeronautical University team is led by Richard Anderson. This team is located in Florida. Their aircraft is the EcoEagle, a modified Stemme S-10. This motor glider features a 100 hp Rotax 912 engine, biofuel, a $40 \mathrm{hp}$ electric generator, and lithium polymer batteries. Embry-Riddle is currently registered and has met the FAA inspection. Figure 6 is a picture of the airplane.

\footnotetext{
" "GosHawk" was accessed from the Windward Performance website URL: http://windwardperformance.com/goshawk.phpon 18 August 2011.

$\dagger$ “GREENELIS” was accessed from the Green-Elis website URL: http://www.greenelis.com on 17 August 2011.

" "The Eco-Eagle" was accessed from the Embry-Riddle Aeronautical University team website URL: http://daytonabeach.erau.edu/coe/about-coe/eagle-flight-research-center/projects/external-link-erau-greenaviation.html on 17 August 2011.
} 


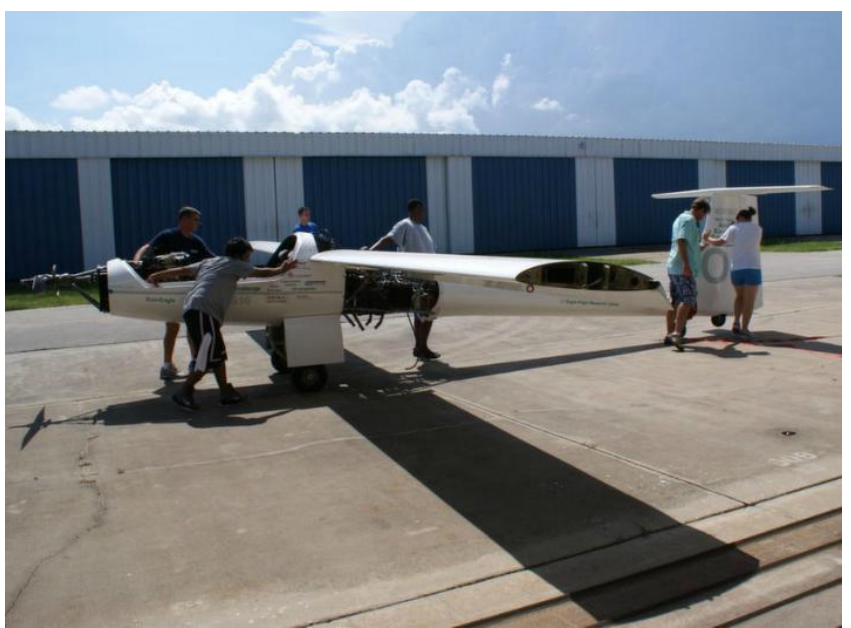

Figure 6. The EcoEagle.

\section{Synergy}

Team Synergy is led by John W. McGinnis. They are located in Montana. Their aircraft is a clean sheet design, featuring laminar flow, wake-immersed propulsion, open thermodynamics, subsonic area ruling, composite construction, and five seats. Synergy is currently registered and has met the FAA inspection. Figure 7 is a conceptual picture of the airplane.*

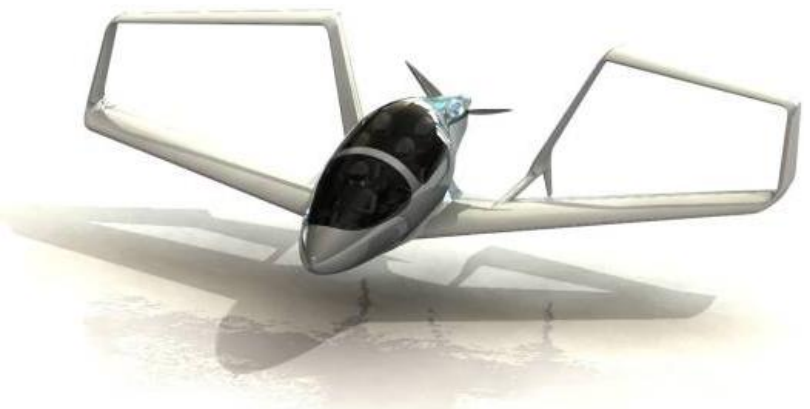

Figure 7. Synergy Aircraft.

\section{GSE-Aerochia}

The GSE-Aerochia team is led by Greg Stevenson from California. Their aircraft is the Econo-Cruiser 3000. It will seat two in tandem and features a bio-fuel hybrid engine. No further details have been released on this aircraft as of the date this paper was written. GSE-Aerochia is not currently registered for the competition. ${ }^{11}$

\section{IKE Aerospace}

The IKE Aerospace team, based in California, is led by Ira Munn. Their aircraft is called the Seraph. The Seraph will incorporate blended wing body, lift body, and biomimicry in its design. It will use monocoque construction to reduce structural weight and ducted propellers for propulsion efficiency and noise reduction. The Seraph will be powered by twin turbine generated electric engines turning counter-rotating propellers. IKE Aerospace is currently registered and has met the FAA inspection. Figure 8 is a conceptual picture of the airplane. ${ }^{\dagger}$

\footnotetext{
* "Synergy" was accessed from the Synergy website URL: http://www.synergyaircraft.com on 17 August 2011.

$\dagger$ "Products" was accessed from the IKE Aerospace website URL: http://www.ikeaerospace.com/products on 17 August 2011.
} 


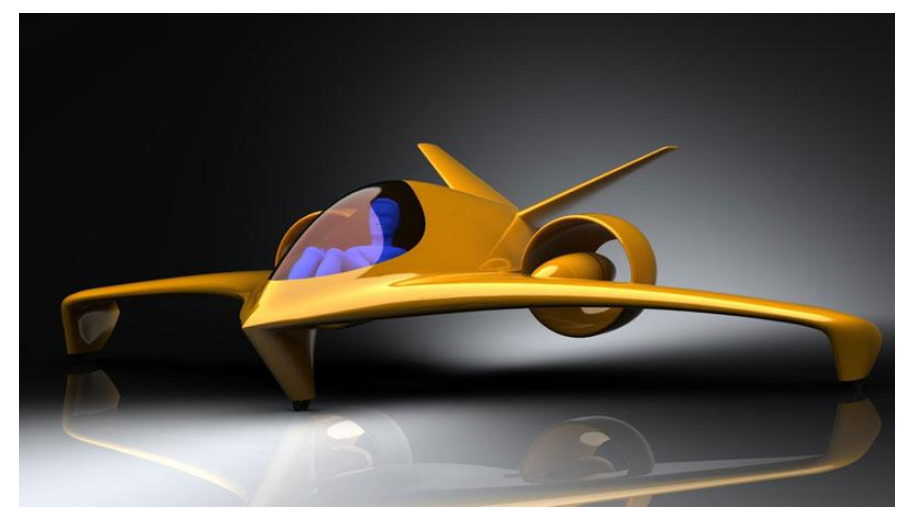

Figure 8. The Seraph.

\section{0.e-Genius}

The e-Genius team is led by Eric Raymond from California. Their aircraft is called the e-Genius. This motor glider features a $60 \mathrm{~kW}$ electric motor with a large diameter propeller. E-Genius has an impressive set of partners including Airbus and the University of Stuttgart in Germany. E-Genius is currently registered, has met the FAA inspection, and the aircraft is currently flying. Figure 9 is a picture of the airplane in flight. ${ }^{12}$

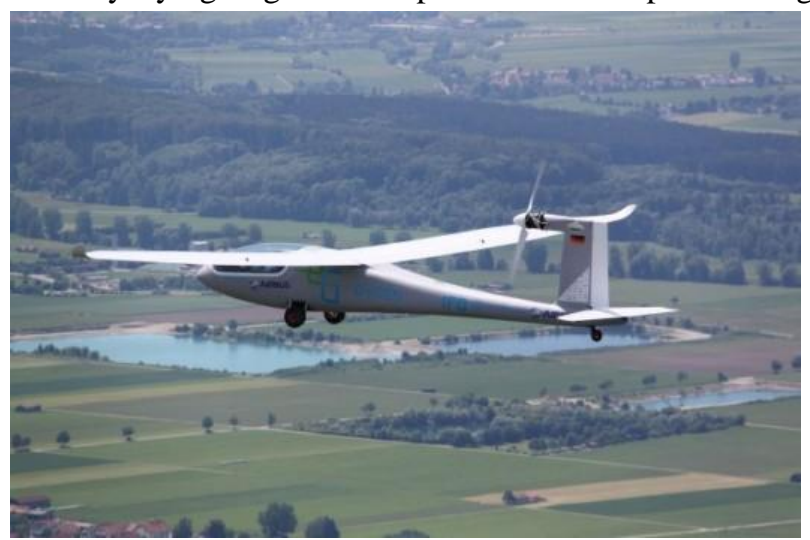

Figure 9. e-Genius.

\section{Phoenix Air}

The Phoenix Air team is led by Jim Lee from Florida. Their aircraft, PhoEnix, is an electric motor glider. It features a modified wing, electric motor, and a retractable landing gear. Phoenix Air is currently registered and has met the FAA inspection. Figure 10 is a picture of the airplane.

\footnotetext{
" "PhoEnix" was accessed from Phoenix Air USA blog URL:

http://phoenixairusa.blogspot.com/2011 0501 archive.html on 17 August 2011.
} 


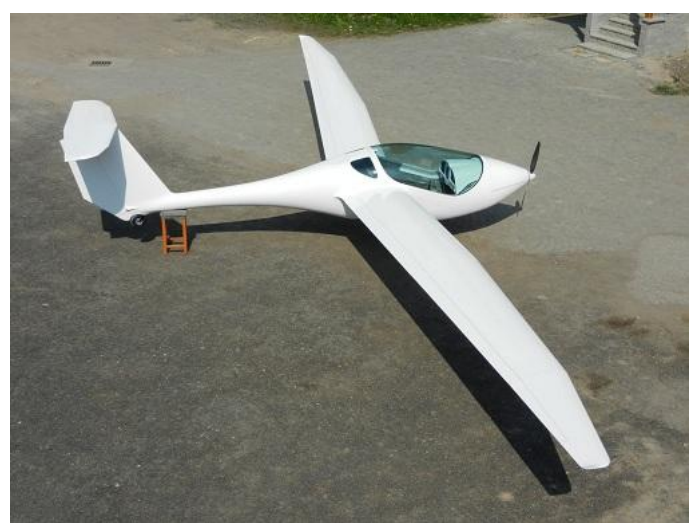

Figure 10. PhoEnix.

\section{Yuneec}

The Yuneec team is led by Scott Sanford from California. Their aircraft is the Yuneec E 1000. It is a three seat electric powered airplane. Yuneec will not be participating in the Green Flight Challenge; sadly the aircraft crashed and took the life of its pilot, Martin Wezel. The crash is believed to have been caused by a structural failure of the tail section ten seconds after takeoff at an altitude of 130 feet.

\section{Pipistrel - Penn. State University}

The Pipistrel - Penn. State University team, based in Pennsylvania, is led by Jack Langelaan. Their aircraft is the Taurus G4. This twin fuselage motor glider features a $145 \mathrm{~kW}$ electric motor, lithium-ion batteries, and retractable landing gear. Pipistrel won the previous CAFE/NASA challenges, the Personal Air Vehicle Challenge in 2007 and the General Aviation Technology Challenge in 2008 with their Virus SW aircraft. The Taurus G4 is currently flying. Pipistrel - Penn. State University is currently registered and has met the FAA inspection. Figure 11 is a picture of the airplane in flight. ${ }^{\dagger}$

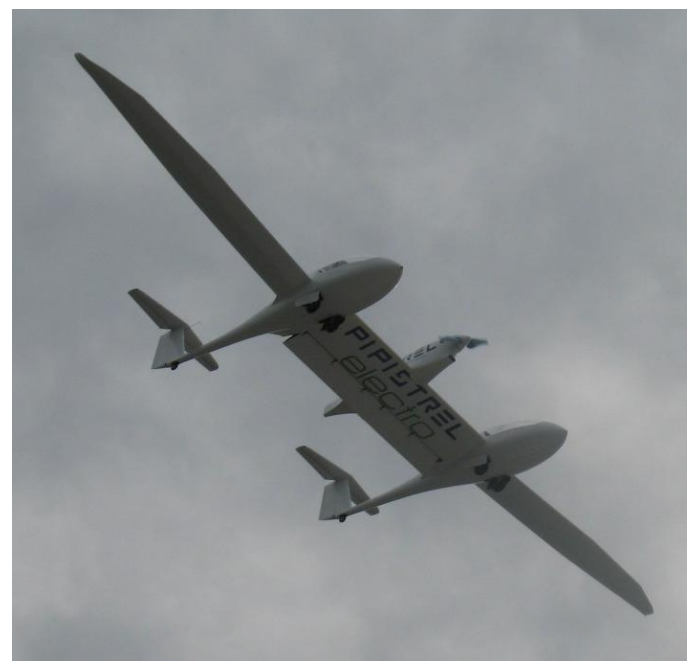

Figure 11. Pipistrel Taurus G4.

\section{The Design Approaches}

\footnotetext{
* "Electric Aircraft Lost: Crash takes life of well-known German pilot" was accessed from the EAA website URL: http://www.eaa.org/news/2011/2011-05-19_yuneec.asp on 17 August 2011.

$\doteqdot$ “Pipistrel's Taurus G4 - The first 4-seat electric aircraft in the world takes flight!" was accessed from the Pipistrel Aircraft website URL: http://www.pipistrel.si/news/pipistrels-taurus-g4--the-first-4seat-electric-aircraft-in-t on 17 August 2011.
} 
There are three main approaches teams could take to reach the Green Flight Challenge goals — increasing aerodynamic, propulsion, and structural efficiency. Approaches to increase aerodynamic efficiency include reducing drag, increasing laminar flow, fuselage shaping, and wake-immersed propulsion. Approaches to increase propulsion efficiency include lighter, more energy dense batteries; Goldschmeid propulsors; lighter, higher power electric motors; electric drive propulsion; slow turning, larger diameter propellers; and efficient ducted propellers. Approaches to increase structural efficiency include the use of composites and other light-weight materials.

The following charts use some key variables to compare current general aviation aircraft similar in size and passenger capacity to the GFC aircraft. These variables — span, empty weight, gross weight, and power-to-weight - provide a quick comparative look into the aerodynamic, structural, and propulsion efficiencies of the aircraft.

Wingspan gives a rough idea of aerodynamic efficiency. A larger span usually indicates a higher aspect ratio for vehicles of the same size. Higher aspect ratio wings tend to have less drag and be more efficient during cruise. Figure 12 shows the 13 GFC teams and four general aviation airplanes' wingspans broken out by number of passengers.

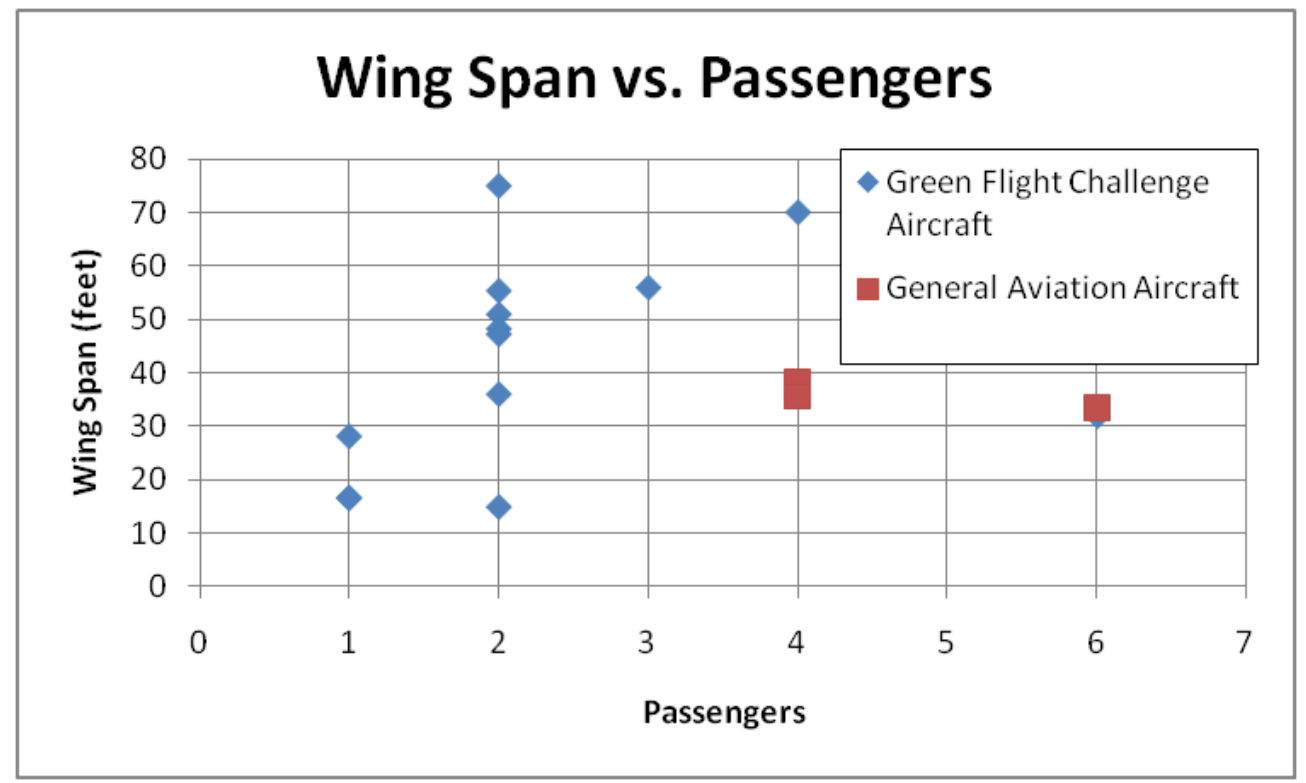

Figure 12. Wingspans of GFC aircraft compared with current general aviation aircraft.

Empty weight gives a rough idea of structural efficiency. A lower empty weight indicates lighter structural weight. Lighter structure enables less powerful and fuel consuming engines. Figure 13 shows five of the GFC teams and four general aviation airplanes' empty weight broken out by number of passengers. 


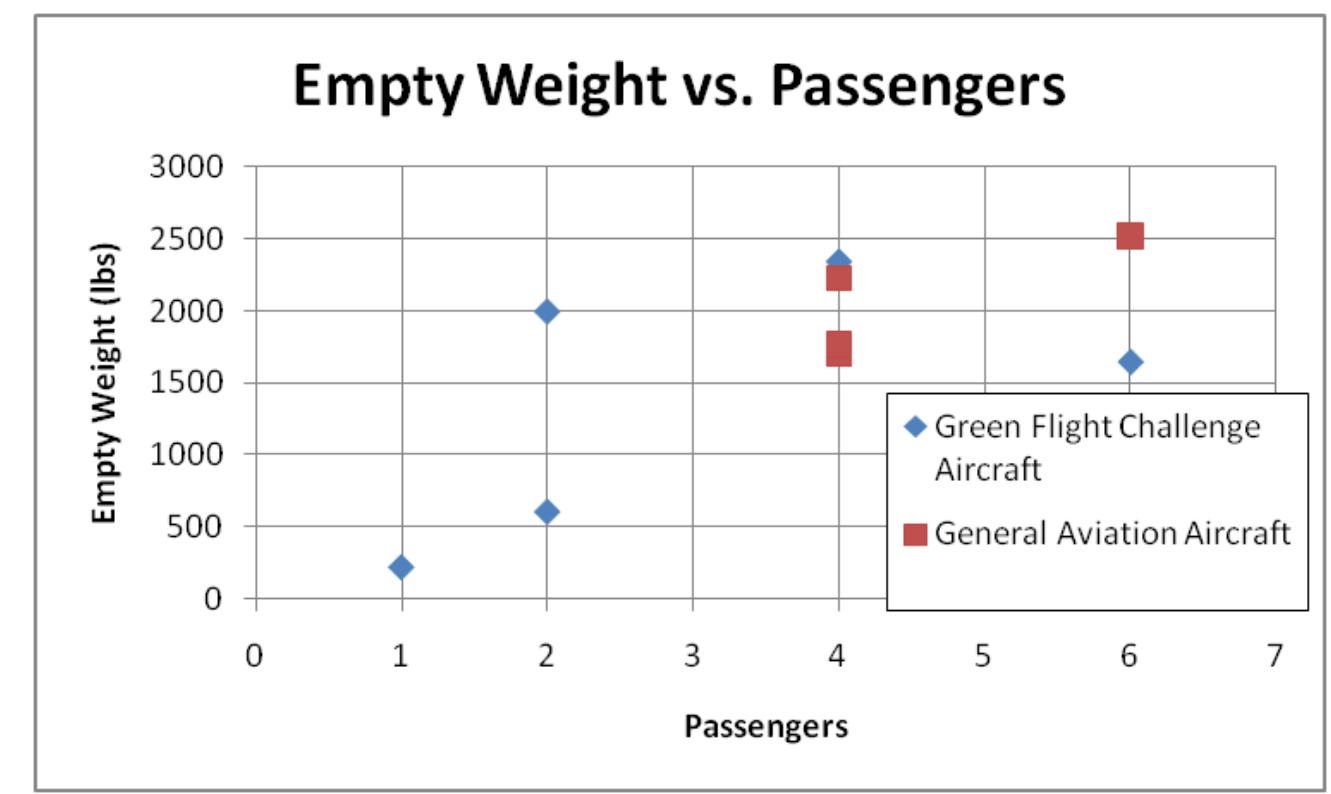

Figure 13. Empty Weight of GFC aircraft compared with current general aviation aircraft.

Figure 14 shows five of the GFC teams and the four general aviation airplanes' power-to-weight ratio by number of passengers. The figure seems to indicate that a lower power-to-weight ratio will result in a higher efficiency. Gross weight and maximum power were used for the power-to-weight ratio of the aircraft in figure 14.

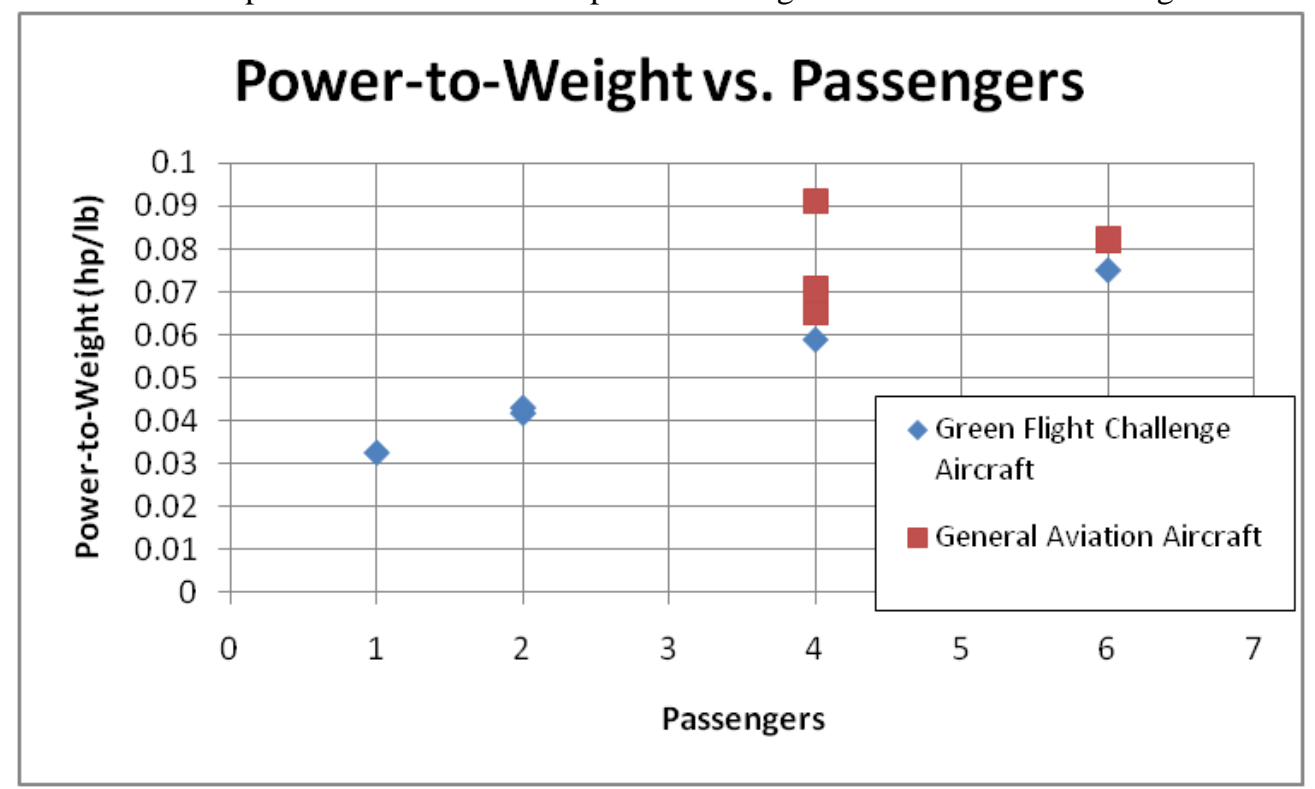

Figure 14. Power-to-weight of GFC aircraft and current general aviation aircraft.

Gross weight gives a rough idea of overall aircraft efficiency. A lower gross weight for an airplane with the same number of passengers and flying the same mission would indicate lighter and more efficient structure. This would enable a smaller engine, which could consume less fuel. Lower gross weight can also indicate less fuel capacity or fuel required for the given mission which means better aerodynamic and propulsive efficiency. Figure 15 shows five of the GFC teams and four general aviation airplanes' gross weight broken out by number of passengers. 


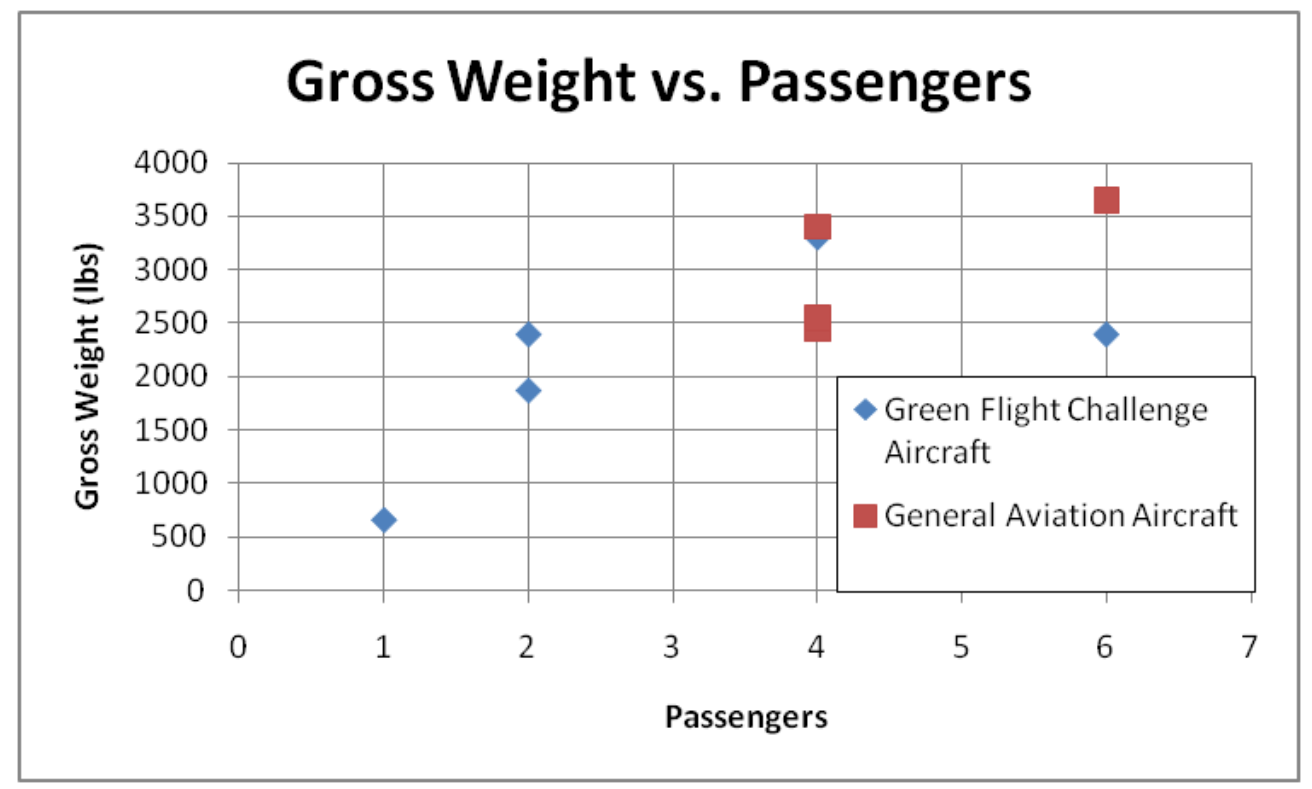

Figure 15. Gross Weight of GFC aircraft compared with current general aviation aircraft.

\section{The Technologies}

The following technologies were listed by the teams as technologies that will be used in their aircraft:

1. Trajectory algorithms - This is the optimization of the cruise speed and altitude in real time using data onboard the aircraft as well as from the ground. These algorithms will enable the aircraft to take advantage of local weather conditions such as wind currents to save more fuel.

2. Batteries - Higher energy density batteries are highly desirable. The lighter the batteries, the lighter the airplane. This is currently one of the biggest problems for electric airplanes. The other big problem is energy density. More energy density will allow longer range.

3. Bio-fuel - Using biomass as fuel. There are a variety of types and mixes, some are blended with petroleum and other traditional fuels. Bio-fuels are being created to burn less fuel and reduce the amount of petroleum dependent products.

4. Electric motors - Lighter weight and more powerful motors are desired. Electric powered aircraft will enable zero emission flight.

5. Ducted propellers - Ducted propellers allow for quieter, higher thrust propulsion than a traditional propeller.

6. Slow turning, large diameter propeller - Compared to a traditional propeller, a larger diameter will allow for the same amount of thrust while the slower speed will enable quieter operation.

7. High efficiency internal combustion engines - Lighter weight, more powerful, and burn less fuel. This will allow for more range, speed, and overall efficiency.

8. Wing tip vortex propellers - These are used to reduce the wake-vortex generated by the wing tip. This would reduce the overall drag and the airplane would burn less fuel.

9. Goldschmied propulsor - This is a type of propulsion that reenergizes the boundary layer from a fuselage for zero net drag. The boundary layer is sucked in at the rear of the fuselage and a propeller accelerates the air out the rear. Figure 16 shows a schematic of a Goldschmied propulsor. 


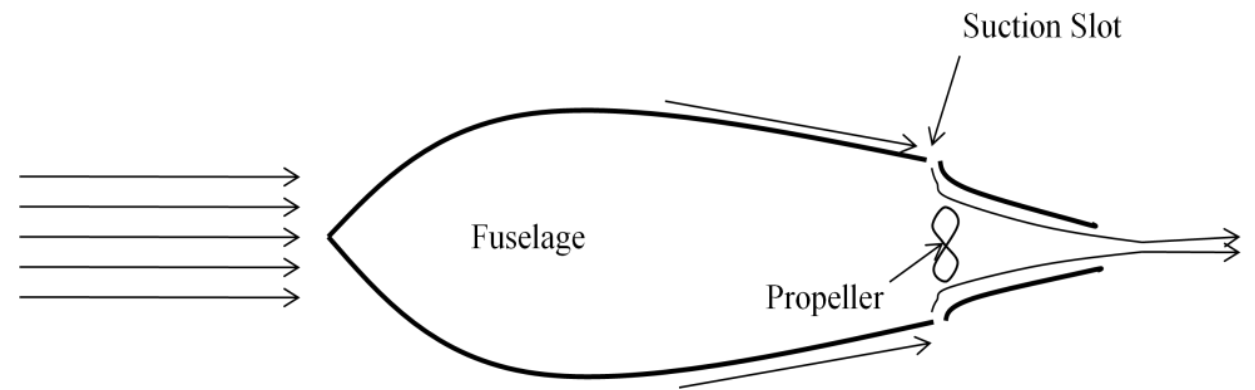

Figure 16. Schematic of Goldschmied propulsor.

10. Wake -immersed propulsion - This concept is very similar to the Goldschmied propulsor. Using the boundary layer from the fuselage for thrust, creating less drag.

11. Electric drive propulsion - Power and drive systems can be separated, which gives more options for positioning each inside of an aircraft. For example, propellers can be located at the wing tip without having a large mass at the tip.

12. Biomimicry - Nature-inspired shaping of the aircraft is believed to create more efficient airplanes.

13. Natural Laminar flow - Natural laminar flow uses shaping on the wing to enable smoother air flow over the wing to reduce drag.

14. Fuselage shaping - This is another laminar flow idea. The idea is to shape the fuselage to enable smooth laminar flow as far back as possible to reduce the drag.

15. Light weight materials, including composites - Lighter and stronger materials will enable lighter aircraft to fly. Lighter aircraft require less thrust and accordingly, less fuel is burned.

There are a wide variety of technologies being pursued for the competition. Some are the traditional aircraft efficiency technologies, while others are relatively new.

\section{Conclusion}

The Green Flight Challenge will take place September 25 - October 1, 2011 at the Charles M. Schulz Sonoma County Airport in California. NASA anticipates a great turnout with more teams participating than the previous two Centennial Challenge Prizes. The quality of the teams and aircraft lead one to believe that the $\$ 1.3$ million prize will be won.

A variety of new aerodynamic, propulsive, and structural technologies will be on display at the competition. The competition was designed to ease the transition of these technologies from competition aircraft to production aircraft. Several of the teams are already promoting their aircraft as production vehicles or prototypes for production vehicles. The end of the Green Flight Challenge will not end the pursuit of an efficient airplane for the general aviation market; it will lead to more efficient civil aircraft that are at least as safe as today. There is an easy connection to general aviation aircraft, but the technologies demonstrated at the Green Flight Challenge will also impact large airliners. Electric aircraft will demonstrate the state-of-the-art battery and motor technologies. Hopefully it will inspire and lead to more technology demonstrations that will change aviation forever.

\section{Acknowledgments}

First and foremost I would like to thank God for the talent He has blessed me with. A special thanks to Mark Moore (NASA Langley Research Center) for his time spent developing the Green Flight Challenge, participating in the rule negotiations, and keeping teams and organizations motivated. Thank you to Andy Hahn (NASA Langley Research Center) for his efforts in setting the "spirit" of the competition. Thank you to Larry Cooper (NASA Headquarters) for overseeing the competition and working with the CAFE Foundation to make the competition happen. In addition, the author would also like to thank CAFE Foundation, and each of the competing teams for the data and information provided. 


\section{References}

${ }^{1}$ Davidian, K., "Prize Competitions and NASA's Centennial Challenges Program," Paper presented at the International Lunar Conference 2005, Sep. 2005.

${ }^{2}$ Davis, L., "How Effective Are Prizes As Incentives To Innovation? Evidence From Three $20^{\text {th }}$ Century Contests," Department of Industrial Economics and Strategy Copenhagen Business School, Copenhagen, Denmark, Jun. 2004.

${ }^{3}$ Alexander, Sonja and Barnstorff, Katherine, "NASA and CAFE Announce Green Aircraft Challenge," NASA Media Advisory: 09-178, Jul. 2009.

4 “2011 CAFE Green Flight Challenge Team Agreement,” rev.07.28.09, CAFE Foundation, Santa Rosa, CA, Jul. 2009.

5 "CAFE 2011 Green Flight Challenge Revised Prize Structure," CAFE Foundation, Santa Rosa, CA, Jun. 2011.

${ }^{6}$ Davis, S. L. and Diegel, S. W., “Transportation Energy Data Book: Edition 22,” ORNL-6967 U.S. Department of Energy, Sep. 2002.

7 “Information Manual Skyhawk SP,” 172SIMBUS-00, Cessna Aircraft Company, Wichita, KS, 2007.

8 "Pilot's Operating Handbook and EASA Approved Airplane Flight Manual for the Cirrus Design SR22," Reissue A 13772001E, Cirrus Design Corporation, Duluth, MN, Oct. 2003.

9 “EASA Type-Certificate Data Sheet Model G36 (Bonanza)," Issue 01 TCDS IM.A.279, European Aviation Safety Agency, May 2009.

10 “Archer III PA-28-181 SN 2843001 and up Pilot's Operating Handbook and FAA Approved Airplane Flight Manual,” VB1611, The New Piper Aircraft Publications Department, Vero Beach, FL, Jul. 1995.

${ }^{11}$ Sigler, Dean, "Lucky 13 to Fly in Green Flight Challenge," CAFE Foundation Blog, [online Blog], URL: http://blog.cafefoundation.org, [cited 17 August 2011].

${ }^{12}$ Sigler, Dean, "Ingenious e-Genius," CAFE Foundation Blog, [online Blog], URL: http://blog.cafefoundation.org, cited 17 August 2011]. 